\title{
The Neuropsychological Profile of Alzheimer Disease
}

\author{
Sandra Weintraub ${ }^{1}$, Alissa H. Wicklund ${ }^{1}$, and David P. Salmon ${ }^{2}$ \\ ${ }^{1}$ Cognitive Neurology and Alzheimer's Disease Center (CNADC), Northwestern University \\ Feinberg School of Medicine, Chicago, Illinois 60611 \\ ${ }^{2}$ Department of Neurosciences, University of California San Diego, La Jolla, California 92093-0662 \\ Correspondence: sweintraub@northwestern.edu
}

\begin{abstract}
Neuropsychological assessment has featured prominently over the past 30 years in the characterization of dementia associated with Alzheimer disease (AD). Clinical neuropsychological methods have identified the earliest, most definitive cognitive and behavioral symptoms of illness, contributing to the identification, staging, and tracking of disease. With increasing public awareness of dementia, disease detection has moved to earlier stages of illness, at a time when deficits are both behaviorally and pathologically selective. For reasons that are not well understood, early AD pathology frequently targets large-scale neuroanatomical networks for episodic memory before other networks that subserve language, attention, executive functions, and visuospatial abilities. This chapter reviews the pathognomonic neuropsychological features of AD dementia and how these differ from "normal," age-related cognitive decline and from other neurodegenerative diseases that cause dementia, including cortical Lewy body disease, frontotemporal lobar degeneration, and cerebrovascular disease.
\end{abstract}

$\mathrm{O}$ ver the past 30 years, neuropsychological assessment has featured centrally in characterizing the dementia associated with Alzheimer disease $(\mathrm{AD})$, identifying the most salient and earliest cognitive and behavioral symptoms and contributing to the staging and tracking of disease (Flicker et al. 1984; Morris et al. 1989; Storandt and Hill 1989; Storandt 1991; Welsh et al. 1991, 1992; Locascio et al. 1995; Albert 1996; Storandt et al. 1998; see also Salmon and Bondi 2009). As research has increasingly focused on earlier stages of illness, it has become clear that biological markers of $\mathrm{AD}$ can precede cognitive and behavioral symptoms by years. It has also become clear that the early symptoms of $\mathrm{AD}$ represent the selective targeting by disease of specific, "largescale" neuroanatomical networks, with clinical deficits consistent with the anatomical locus of impact (Weintraub and Mesulam 1993, 1996, 2009; Seeley et al. 2009). In the usual case, $\mathrm{AD}$ pathology is initially selective for limbic regions that subserve episodic memory, which leads to a circumscribed memory deficit in the early stages of the disease (Braak and Braak 1991; Jack et al. 1997; de ToledoMorrell et al. 2000). It is only as pathology progresses to other neocortical regions over time

Editors: Dennis J. Selkoe, Eckhard Mandelkow, and David M. Holtzman

Additional Perspectives on The Biology of Alzheimer Disease available at www.perspectivesinmedicine.org

Copyright (C) 2012 Cold Spring Harbor Laboratory Press; all rights reserved; doi: 10.1101/cshperspect.a006171

Cite this article as Cold Spring Harb Perspect Med 2012;2:a006171 
S. Weintraub et al.

(Braak and Braak 1996a,b; Braak et al. 1999; Jack et al. 2000) that additional cognitive symptoms emerge and the full dementia syndrome becomes apparent.

These discoveries have prompted a revision of the established research diagnostic criteria for $\mathrm{AD}$ dementia that had served so well since 1984 (McKhann et al. 1984). The new criteria define not only the dementia of AD (McKhann et al. 2011) but also incorporate a fuller spectrum of cognitive aging, including an intermediate stage of mild cognitive impairment (MCI) that precedes the dementia (Albert et al. 2011). A third, even earlier, stage of "preclinical AD" has also been identified (Sperling et al. 2011). This prodromal period is characterized by the presence of biomarkers, such as brain amyloid deposition and CSF tau and amyloid, that can be detected in vivo in asymptomatic individuals years before the onset of cognitive decline (Perrin et al. 2009; Sperling et al. 2009; Jack et al. 2010). At present, the recommended use of biomarkers to detect $\mathrm{AD}$ applies mainly to research. Thus, neuropsychological assessment continues to provide reliable symptom markers of $\mathrm{AD}$ that are critical for early diagnosis. The present article describes the profile of neuropsychological deficits associated with the dementia of $\mathrm{AD}$ and contrasts it with cognitive changes that occur in "normal" aging and in other forms of neurodegenerative disease that cause dementia.

\section{NEUROPSYCHOLOGICAL DEFICITS IN ALZHEIMER DISEASE}

\section{Episodic Memory}

The earliest neurofibrillary changes that are part of the pathology of AD usually occur in medial temporal lobe structures (e.g., hippocampus, entorhinal cortex; see Braak and Braak 1991), interrupting the neural network critical for episodic memory function. Thus, it is not surprising that a deficit in the ability to learn and remember new information (i.e., anterograde amnesia) is the clinical hallmark of $\mathrm{AD}$ pathology. However, the amyloid pathology that likely occurs years prior to the onset of symptoms (Morris et al. 1996; Reiman et al. 1996; Moonis et al. 2005; Mintun et al. 2006; Becker et al. 2010; De Meyer et al. 2010) is not particularly abundant in medial temporal lobe, but instead in the regions comprising the "default mode network" (Buckner et al. 2005; Sperling et al. 2009). These changes in the default mode network, comprised of a set of functionally interconnected cortical areas (posterior cingulate, inferior parietal lobule, lateral temporal neocortex, ventromedial and dorsomedial prefrontal cortex) that project heavily to medial temporal lobe structures (Buckner et al. 2008), presage cell death in the hippocampus by years.

Numerous studies have shown that patients with $\mathrm{AD}$ are impaired on episodic memory tests that use a variety of cognitive procedures (e.g., free recall, recognition, paired-associate learning) across virtually all modalities (e.g., auditory, visual, olfaction) (for review, see Salmon 2000). Evidence from many of these studies suggests that the episodic memory deficit of $\mathrm{AD}$ patients is due in large part to ineffective consolidation or storage of new information. Early studies that characterized the episodic memory deficit in $\mathrm{AD}$ used word list learning tasks such as those from the Consortium to Establish a Registry for Alzheimer Disease (CERAD) (Welsh et al. 1991) and the California Verbal Learning Test (CVLT) (Delis et al. 1991). These studies consistently showed that $\mathrm{AD}$ patients rapidly forget information over time and are equally impaired (relative to age-matched controls) on recognition and free recall components of the tasks. This pattern of performance is consistent with impaired consolidation rather than ineffective retrieval of new information (Delis et al. 1991).

Indices of rapid forgetting have important clinical utility for the early detection and differential diagnosis of AD. Welsh and colleagues (1991), for example, found that the amount of information recalled after a 10 -min delay on the CERAD word list learning task differentiated very early $\mathrm{AD}$ patients from healthy elderly controls with better than $90 \%$ accuracy. This measure was superior in this regard to other measures derived from this task, 
including immediate recall on each of three learning trials, recognition memory score, and the number of intrusion errors produced throughout the test. Other studies have shown that measures of rapid forgetting can differentiate mildly demented $\mathrm{AD}$ patients from healthy elderly controls with $\sim 85 \%-90 \%$ accuracy (Flicker et al. 1984; Butters et al. 1988; Knopman and Ryberg 1989; Morris et al. 1991; Welsh et al. 1991; Tröster et al. 1993). Additional mechanisms contributing to episodic memory impairment in $\mathrm{AD}$ include increased sensitivity to interference due to decreased inhibitory processes leading to the production of intrusion errors (Fuld et al. 1982; Jacobs et al. 1990; Delis et al. 1991), and defective use of semantic information to bolster encoding (see Martin et al. 1985; Dalla Barba and Wong 1995; Dalla Barba and Goldblum 1996).

A number of prospective longitudinal studies of cognitive function in nondemented older adults have shown that a subtle decline in episodic memory often occurs before the emergence of the obvious cognitive and behavioral changes required for a clinical diagnosis of $\mathrm{AD}$ (Bondi et al. 1994; Jacobs et al. 1995; Linn et al. 1995; Grober and Kawas 1997; Howieson et al. 1997; Small et al. 2000; Backman et al. 2001; Kawas et al. 2003). Some of these studies suggest that memory performance may be poor, but stable, a number of years before the development of the dementia syndrome, and then declines rapidly in the period immediately preceding the AD dementia diagnosis. Small et al. (2000) and Backman et al. (2001), for example, found that episodic memory was mildly impaired 6 yr before dementia onset, but changed little over the next 3 yr. Chen et al. (2001) and Lange et al. (2002) showed a significant and steady decline in episodic memory on delayed recall conditions of word list and story memory tests beginning $\sim 3 \mathrm{yr}$ before the dementia diagnosis in individuals who were either initially asymptomatic or met criteria for MCI at enrollment in these longitudinal studies. Taken together, these studies suggest that an abrupt decline in memory in an elderly individual might better predict the imminent onset of dementia than poor but stable memory ability. These and similar findings led to the development of formal criteria for amnestic MCI (see Petersen et al. 2001), a predementia condition in elderly individuals, which is characterized by subjective and objective memory impairment that occurs in the face of relatively preserved general cognition and functional abilities (for reviews, see Collie and Maruff 2000; Albert and Blacker 2006).

\section{Language and Semantic Knowledge}

Mildly demented patients with $\mathrm{AD}$ are often impaired on tests of object naming (Bayles and Tomoeda 1983; Martin and Fedio 1983; Bowles et al. 1987; Hodges et al. 1991), verbal fluency (Martin and Fedio 1983; Butters et al. 1987; Monsch et al. 1992), and semantic categorization (Aronoff et al. 2006). The underlying nature of these deficits has been debated (see Nebes 1989) but there is evidence that they reflect deterioration in the structure and content of semantic memory (i.e., general knowledge of facts, concepts, and the meanings of words) that supports language. Knowledge for particular items or concepts and the associations between them may be disrupted as the neuropathology of $\mathrm{AD}$ encroaches upon the temporal, frontal, and parietal association cortices in which they are thought to be diffusely stored (for review, see Hodges and Patterson 1995).

Evidence for a deterioration of semantic memory in $\mathrm{AD}$ comes from several studies that probed for knowledge of particular concepts across different modes of access and output (e.g., fluency, confrontation naming, sorting, word-to-picture matching, and definition generation). These studies assume that loss of knowledge, as opposed to impaired retrieval of intact knowledge, would lead to consistency of performance across items (Chertkow and Bub 1990; Hodges et al. 1992). For example, if a patient has lost the concept of "horse," they should not be able to name a picture of a horse, generate "horse" on a verbal fluency test, sort horse into its proper category as a domestic animal, and so on. The results of these studies 
S. Weintraub et al.

showed that patients with $\mathrm{AD}$ were significantly impaired on all measures of semantic memory and, when a particular stimulus item was missed (or correctly identified) in one task, it was likely to be missed (or correctly identified) in other tasks that accessed the same information in a different way.

Loss of knowledge of the attributes and associations that define a particular semantic category is also thought to reduce the ability of patients with $\mathrm{AD}$ to efficiently generate words from a small and highly related set of exemplars during tests of verbal fluency. Thus, patients with $\mathrm{AD}$ are more impaired on category fluency (e.g., generating lists of animals) than letter fluency (e.g., generating words beginning with a specific letter) (Butters et al. 1987; Monsch et al. 1992; Henry et al. 2004, 2005). The fact that patients with $\mathrm{AD}$ are more impaired on the fluency task that places greater demands on the integrity of semantic memory is consistent with the notion that they have a deterioration in the structure and organization of semantic memory rather than a general inability to retrieve or access semantic knowledge (see also Rohrer et al. 1995, 1999).

\section{Executive Functions, Working Memory, and Attention}

Deficits in "executive functions" responsible for the mental manipulation of information, concept formation, problem solving, and cuedirected behavior occur early in the course of $\mathrm{AD}$ and are often evident in the MCI stage (Perry and Hodges 1999; Chen et al. 2001). Executive function deficits in addition to difficulties with delayed memory recall predict subsequent progression to $\mathrm{AD}$ dementia (Albert 1996). Reduced ability to mentally manipulate information may be a particularly early feature based on a well-controlled study showing that very mildly demented $\mathrm{AD}$ patients were significantly impaired relative to cognitively normal controls on tests that required set shifting, selfmonitoring, or sequencing, but not on tests that required cue-directed attention or verbal problem solving (Lefleche and Albert 1995). A number of other studies have similarly shown that
$\mathrm{AD}$ patients are impaired on difficult problemsolving tests that require mental manipulation such as the Tower of London puzzle (Lange et al. 1995), the modified Wisconsin Card Sorting Task (Bondi et al. 1993), tests of relational integration (Waltz et al. 2004), and other tests of executive functions such as the Porteus Maze Task, Part B of the Trail-Making Test, and the Raven Progressive Matrices (Grady et al. 1988). These deficits in executive functioning have been hypothesized to reflect AD pathology, especially neurofibrillary tangle burden, in prefrontal cortex. This regional prefrontal cortex pathology is particularly pronounced in a subset of $\mathrm{AD}$ patients who present early on with predominant executive dysfunction (Johnson et al. 1999; Waltz et al. 2004). This again highlights the impact of anatomical specificity of pathology on the disruption of distinct neocortical networks.

The deficit in mental manipulation exhibited by patients with $\mathrm{AD}$ may also be expressed on tests of working memory. "Working memory" refers to a processing system whereby information that is the immediate focus of attention is temporarily held in a limitedcapacity, language- or visually-based, immediate memory buffer while being manipulated by a "central executive" (Baddeley 2003). Studies indicate that the working memory deficit of patients with $\mathrm{AD}$ is initially mild and primarily involves disruption of the central executive with relative sparing of immediate memory (Baddeley et al. 1991; Collette et al. 1999). It is not until later stages of $\mathrm{AD}$ that all aspects of the working memory system become compromised (Baddeley et al. 1991; Collette et al. 1999). Consistent with this model, mildly demented AD patients are often impaired on complex attention tasks that are dependent upon the effective allocation of attentional resources (e.g., dual-processing tasks) or that require efficient disengagement and shifting of attention (for reviews, see Parasuraman and Haxby 1993; Perry and Hodges 1999). In contrast, the ability to focus and sustain attention is usually only affected in later stages of the disease. This is apparent in the essentially normal performance of mildly demented $\mathrm{AD}$ patients on tests of immediate 
attention span compared with supraspan tests (Cherry et al. 2002).

\section{Visuospatial Abilities}

Patients with AD often exhibit deficits in visuospatial abilities at some point in the course of the disease (for review, see Cronin-Golomb and Amick 2001). It has also been suggested that visuospatial deficits may occur early, even in preclinical stages (Johnson et al. 2009). Changes in visuospatial function are apparent on visuoconstructional tasks and tasks that require visuoperceptual abilities and visual orientation. The visuoperceptual deficit exhibited by patients with $\mathrm{AD}$ may arise, in part, from the loss of effective interaction between distinct and relatively intact cortical information processing systems (Morrison et al. 1991). Studies have shown, for example, that when $\mathrm{AD}$ patients perform a visual search task to quickly identify targets on the basis of the conjunction of two or more features that are processed in different cortical regions (e.g., color and shape), they have disproportionately greater response times compared to controls than when required to identify targets solely on the basis of a single feature (Treisman 1996; Foster et al. 1999). Subsequent studies showed that this deficit in "feature-binding" (Treisman 1996; Foster et al. 1999) could not be attributed to the different attentional demands inherent in conjunction versus single-feature visual search tasks (Tales et al. 2002) A similar deficit was observed by Festa and colleagues (2005) on a task that required corticocortical integration of motion and color information which is processed in distinct dorsal (motion) and ventral (color) cortical visual information processing "streams."

Deficits in visual information processing and in selective and divided attention are observed in the course of normal aging but are exacerbated in individuals with $\mathrm{AD}$ (Parasuraman et al. 1995, 2000; Greenwood and Parasuraman 1997; Greenwood et al. 1997; Parasuraman and Greenwood 1998). In addition, visual motion detection has been shown to decline in some individuals with MCI, and more so in those with a diagnosis of $\mathrm{AD}$ dementia, suggesting that this symptom may constitute an independent marker of those likely to have AD pathology (Mapstone 2003). The narrowing of the window of visuospatial attention has been demonstrated with the Useful Field of View (UFOV) paradigm in which reaction time to peripheral visual targets is measured in the presence of various levels of distracting visual stimuli (Ball et al. 1988). Older individuals react more slowly to peripheral stimuli compared to younger controls, and patients with $\mathrm{AD}$ show an even greater impairment. These deficits may account for the increased incidence of car crashes in patients with AD dementia (Rizzo et al. 1997; Ball and Owsley 2003).

Although rare, $\mathrm{AD}$ can initially present with relatively circumscribed posterior cortical atrophy (PCA), with dementia dominated by higher order visual dysfunction (see Caine 2004). Despite relatively preserved memory functions, intact language, and preserved judgment and insight, patients with the clinical syndrome of PCA usually have prominent visual agnosia, constructional apraxia, and exhibit some or all of the features of Balint's syndrome including optic ataxia, gaze apraxia, and simultanagnosia. They may also exhibit components of Gerstmann's syndrome including acalculia, rightleft disorientation, finger agnosia, and agraphia. A visual field defect, decreased visual attention, impaired color perception, or decreased contrast sensitivity may also occur (Della Sala et al. 1996).

The clinical syndrome of PCA is usually associated with $\mathrm{AD}$ pathology but may also occur in the presence of neuropathological changes of cortical Lewy body disease or CreutzfeldJakob disease. Neuropathologic examination reveals disproportionate atrophy and pathologic lesions in the occipital cortex and posterior parietal cortex (Hof et al. 1997; Renner et al. 2004). Studies using positron emission tomography (PET) have shown particular involvement of the dorsal visual stream (Nestor et al. 2003). In the case of PCA due to AD, neurofibrillary tangles and neuritic plaques in the posterior cortical regions are qualitatively identical to those in typical AD (Hof et al. 1997). 
S. Weintraub et al.

The disproportionately posterior cortical distribution of $\mathrm{AD}$ pathology in PCA has recently been shown in living patients using PET imaging with Pittsburgh compound-B ([ $\left.\left.{ }^{11} \mathrm{C}\right]-\mathrm{PIB}\right)$, an agent that binds to $\beta$ amyloid in the brain (Tenovuo et al. 2008).

\section{DISTINGUISHING ALZHEIMER DISEASE FROM OTHER CAUSES OF DEMENTIA}

Although AD is the leading cause of dementia in the elderly, dementia can arise from a wide variety of etiologically and neuropathologically distinct disorders that give rise to somewhat different patterns of cognitive impairment. Knowledge of these differences might lead to better understanding of the neurobiological basis of normal and abnormal cognition and have important implications for differential diagnosis. Increasingly, AD pathology has been identified following a distribution other than the canonical temporal-limbic trajectory. Progressive visuospatial deficits, executive dysfunction, and aphasia syndromes have been described in association with AD pathology (Hof et al. 1993; Johnson et al. 1999; Mesulam 2008). Clinical criteria have shown diagnostic accuracy for AD (Dubois et al. 2007), but lack specificity in differentiating $\mathrm{AD}$ from other dementia syndromes. The lack of differentiation is due, in part, to the fact that, although memory impairment is a hallmark of $\mathrm{AD}$, it may also occur with other neurodegenerative diseases. The remaining sections will review similarities and differences between the cognitive deficits of $\mathrm{AD}$ and those of other age-related causes of dementia: dementia with Lewy bodies (DLB), frontotemporal lobar degeneration (FTLD), and vascular dementia (VaD).

\section{Alzheimer Disease versus Dementia with Lewy Bodies}

DLB is a clinicopathologic condition characterized by cell loss and the presence of Lewy bodies $(\alpha$-synuclein positive intracytoplasmic neuronal inclusion bodies) in subcortical regions affected in Parkinson's disease and diffusely distributed throughout the limbic system and neocortex. In most cases, $\mathrm{AD}$ pathology also occurs in the same general distribution as in "pure" AD (Ince et al. 1998). The dementia syndrome of DLB is similar to that of $\mathrm{AD}$ and the two disorders are often clinically confused during life (e.g., Hansen et al. 1990; Merdes et al. 2003). However, mild spontaneous motor features of Parkinsonism (e.g., bradykinesia, rigidity, and masked facies, but without a resting tremor), recurrent and well-formed visual hallucinations, and fluctuating cognition with pronounced variations in attention or alertness occur more frequently in patients with DLB than in those with pure AD (for review, see McKeith et al. 2005).

There are subtle differences in the patterns of neuropsychological deficits associated with DLB and AD. Studies comparing clinically diagnosed or autopsy-diagnosed patient groups on batteries of neuropsychological tests suggest that visuospatial, attention, and executive function deficits are more pronounced in DLB than $\mathrm{AD}$ (at the same stage of global dementia severity), whereas memory impairment is more pronounced and may be qualitatively different in AD compared to DLB (Hansen et al. 1990; Johnson et al. 2005; Kraybill et al. 2005; Ferman et al. 2006; Guidi et al. 2006; Stavitsky et al. 2006). These studies also suggest that the severity of the visuospatial deficit may be the most salient difference between patients with $\mathrm{AD}$ and patients with DLB, perhaps because of significant occipital cortex dysfunction only in the latter group. Studies using PET or SPECT neuroimaging have shown that patients with DLB have hypometabolism and decreased blood flow in primary visual and visual association cortex that is not evident in AD (Minoshima et al. 2001). They also have unique occipital cortex pathology that includes white matter spongiform change with coexisting gliosis (Higuchi et al. 2000), and in some cases deposition of Lewy bodies (e.g., Gomez-Tortosa et al. 2000).

The prominence of the visuospatial deficits in DLB has important clinical utility. In one study, for example, the presence of visual hallucinations was the best positive predictor (positive predictive value: $83 \%$ ) of DLB (vs. AD) at 
autopsy, whereas lack of visuospatial impairment was the best negative predictor (negative predictive value: 90\%) (Tiraboschi et al. 2006). In another study, Hamilton and colleagues (2008) showed that poor baseline performance on visuospatial tests, but not tests of other cognitive abilities, was strongly associated with a rapid rate of global cognitive decline over the subsequent two years in patients with DLB but not in those with AD. Thus, early severe visuospatial deficits may identify DLB patients who face a particularly malignant disease course.

The memory deficit of patients with DLB is generally less severe than that of patients with $\mathrm{AD}$ and may reflect a qualitative difference in the processes affected. This was shown in a study that directly compared the performance of patients with autopsy-confirmed DLB (all with concomitant $\mathrm{AD}$ pathology) or with pure $\mathrm{AD}$ on the CVLT and the WMS-R logical memory test (Hamilton et al. 2004). Although the two groups were equally impaired in their ability to learn new verbal information on these tests, the DLB patients exhibited better retention and better recognition memory than patients with pure $\mathrm{AD}$. The better retention and recognition memory of the DLB patients suggests that a deficit in retrieval plays a greater role in their memory impairment than in that of patients with $\mathrm{AD}$.

\section{Alzheimer Disease versus Frontotemporal Lobar Degeneration}

FTLD encompasses a class of neurodegenerative diseases that share an affinity for the frontal and temporal lobes of the brain and are marked by distinctive neuropathologic features. The dementia syndromes associated with FTLD are characterized by the absence of true amnesia in the early stages. Instead, they can be divided into two broad categories: a language-based dementia referred to as primary progressive aphasia (PPA) (Mesulam 1982, 2001, 2003), and a dementia in which changes in social cognition, behavior and personality mark the earliest stages, known as behavioral variant frontotemporal dementia (bvFTD) (Rascovsky et al. 2007a, 2011).
The earliest characterization of a dementia marked by significant personality changes was initially called "frontal lobe dementia" and shown to be related to Pick's disease (i.e., neocortical deposition of Pick bodies) and to nonspecific neuropathology designated as "frontal lobe degeneration of non-Alzheimer type" (Brun 1987; Gustafson 1987). Subsequent classification led to the delineation of three syndromes, namely, frontotemporal dementia, progressive nonfluent aphasia, and semantic dementia (Neary et al. 1994, 1998; Neary and Snowden 1996). However, rapid accumulation of information on the neuroimaging and neuropathologic features of these non-AD dementias over the past decade has necessitated further revision of the clinical and neuropathologic diagnostic criteria, which are likely to continue to evolve.

Beginning about 20 years ago, neuropathologic entities associated with FTLD syndromes were designated as either a form of tauopathy or as "dementia lacking distinctive histopathology” (Knopman et al. 1990). As clinical, pathological, and molecular characterization was enhanced over subsequent years, new discoveries led to an increase in the number of pathologic diagnoses that now fall under the rubric of FTLD. At present, the neuropathologic diagnosis is based on the molecular nature of intraneuronal inclusions, which include tarDNA binding protein (TDP-43), fused-in-sarcoma protein (FUS), entities characterized by different molecular forms of tau, and a smaller class of as yet uncharacterized entities (Mackenzie et al. 2010). Genetic mutations in tau, progranulin, valosin-containing protein (VCP) (Watts et al. 2004), and CHMP2B (Skibinski et al. 2005; Holm et al. 2007) have been associated with frontotemporal dementia syndromes. Neuroimaging studies have shown that left perisylvian language regions show the most marked structural changes and salient hypometabolism in patients with PPA (Sonty et al. 2003; GornoTempini et al. 2004), whereas bilateral frontal and anterior temporal atrophy and hypometabolism characterize bvFTD (Whitwell et al. 2004, 2009; Knopman et al. 2009). These patterns are distinct from the well-known medial temporal 
S. Weintraub et al.

lobe atrophy (Jack et al. 1997) and bilateral temporoparietal hypometabolism (Foster et al. 1983) associated with typical AD dementia.

\section{Primary Progressive Aphasia}

There has been growing interest in PPA since the modern-day description of six patients with "slowly progressive aphasia" (Mesulam 1982). Three variants have been defined, each with a distinctive clinical, neuroanatomic, and neuropathologic profile (Mesulam et al. 2008, 2009; Gorno-Tempini et al. 2011). Nonfluent/agrammatic PPA (PPA-G), is characterized by deficits in grammatical features of language with or without nonfluent speech output. PPA-G has been associated predominantly with FTLD-tauopathy (Mesulam et al. 2008; Grossman 2010). Semantic variant PPA (PPA-S) is characterized by fluent speech production and single word comprehension deficits. PPA-S is mainly associated with the pathology of TDP-43 proteinopathy (Mesulam et al. 2008). PPA-S overlaps with semantic dementia, a disorder in which there are visual processing deficits in addition to aphasia (see Hodges and Patterson 2007). A third variant, logopenic PPA (PPA-L), is characterized by hesitant, grammatically correct speech and spared language comprehension (Gorno-Tempini et al. 2004; Mesulam et al. 2009). PPA-L is most often associated with $\mathrm{AD}$ pathology disproportionately distributed in language-related cortical areas (Mesulam et al. 2008). Patients with a familial form of PPA due to a progranulin mutation have been reported to have disproportionate TDP-43 pathology in language-related areas in the left cerebral hemisphere (Gliebus et al. 2009).

As mentioned earlier, anomia and reduced word list generation are features of $\mathrm{AD}$ that may be indicative of a more general dissolution of semantic processing. In contrast, anomia and verbal fluency deficits in PPA can occur without associated semantic loss. Early language deficits in PPA also include agrammatism, phonological sequencing deficits, and paraphasias in speech. In typical $\mathrm{AD}$ these types of language deficits occur only in advanced stages of disease in which patients may develop frank aphasia against a background of more widespread cognitive dysfunction (Bayles 1982). A greater deficit in naming verbs than naming nouns is associated with nonfluent, agrammatic forms of PPA (Hillis et al. 2004). Verb processing deficits can also occur in $\mathrm{AD}$, but the deficits are linked to impaired processing of the semantic rather than the syntactic information carried by verbs (Grossman et al. 1996; Kim and Thompson 2004).

Neuropsychological studies that directly compared patients with clinically diagnosed PPA, bvFTD, and AD have shown that those with PPA have relatively preserved reasoning and episodic memory compared with the other two groups (Wicklund et al. 2004, 2006). Furthermore, functional ability reflected in activities of daily living (ADL) is better preserved in patients with PPA than in the other two groups when duration of illness is controlled (Wicklund et al. 2007). Perhaps this occurs because the relative preservation of episodic memory and judgment in patients with PPA is less detrimental to complex ADL than aphasia, at least initially. Language deficits are most prominent in PPA early in the course of illness, but also develop and worsen in patients with bvFTD. Language deficits have a more indolent course in $\mathrm{AD}$ than in PPA or bvFTD (Blair et al. 2007).

\section{Behavioral Variant Frontotemporal Dementia}

The behavioral variant of FTD usually begins insidiously with personality and behavioral changes such as inappropriate social conduct, inertia and apathy, disinhibition, perseverative behavior, loss of insight, hyperorality, and decreased speech output (for reviews, see Miller et al. 1997; Snowden et al. 2001; Rascovsky et al. 2007a; Rabinovici et al. 2008; Caycedo et al. 2009). These changes are followed by cognitive deficits which include alterations in judgment, problem solving, concept formation, and executive functions, often with relative sparing of visuospatial abilities and episodic memory. BvFTD and probable AD can be difficult to distinguish during life because of overlap in symptoms, but it has been suggested that $\mathrm{AD}$ is more 
often associated with constructional deficits than bvFTD. Although recent attempts to differentiate bvFTD and $\mathrm{AD}$ on the basis of the nature and severity of behavioral symptoms has met with some success (e.g., Barber et al. 1995, 2000; Miller et al. 1997; Mendez et al. 1998; Bozeat et al. 2000; Kertesz et al. 2000), behavior-based methods are only partially effective and might be improved by considering other aspects of the disorders. This has led some researchers to investigate the possibility that differences in the patterns of cognitive deficits associated with bvFTD and AD might aid in differential diagnosis (Elfgren et al. 1994; Binetti et al. 1996; Mendez et al. 1996; Pachana et al. 1996; Thomas-Anterion et al. 2000; Rascovsky et al. 2002; Kramer et al. 2003). Revised criteria for the clinical diagnosis of bvFTD have recently been validated against pathologically verified FLTD (Rascovsky et al. 2011), which may improve diagnostic accuracy.

Particularly compelling are retrospective studies that have shown a double dissociation in which mildly to moderately demented patients with autopsy-confirmed FTLD are more impaired than those with autopsy-confirmed $\mathrm{AD}$ on tests sensitive to frontal lobe dysfunction (e.g., word generation tasks), but less impaired on tests of memory and visuospatial abilities sensitive to dysfunction of medial temporal and parietal association cortices (e.g., Rascovsky et al. 2002; Grossman et al. 2007). In one study, Rascovsky and colleagues (2002) used multivariate analysis of covariance to show that FTLD patients performed significantly worse than $\mathrm{AD}$ patients on word generation tasks that are sensitive to frontal lobe dysfunction (particularly letter fluency), but significantly better on tests of memory (i.e., Mattis Dementia Rating Scale [DRS] Memory subscale) and visuospatial abilities (i.e., WAIS Block Design and Clock Drawing tests), which are sensitive to dysfunction of medial temporal and parietal association cortices, respectively. A logistic regression model using scores from letter fluency, the Mattis DRS memory subscale, and the Block Design test correctly classified $91 \%$ of $\mathrm{AD}$ patients and $77 \%$ of FTLD patients. A follow-up study (Rascovsky et al. 2007b) that compared the performance of autopsy-confirmed FTLD and AD patients on letter and semantic category fluency tasks showed that FTLD patients performed worse than $\mathrm{AD}$ patients overall and showed similar impairment in letter and semantic category fluency, whereas $\mathrm{AD}$ patients showed greater impairment in semantic fluency than letter fluency. A measure of the disparity between letter and semantic fluency (the Semantic Index) correctly classified 26 of $32 \mathrm{AD}$ patients $(82 \%)$ and 12 of 16 FTLD patients (75\%). Interestingly, the few misclassified FTLD subjects all had clinical presentations of PPA. When these cases were excluded, a dissociation was apparent with letter worse than semantic fluency for the FTLD patients and semantic worse than letter fluency for the $\mathrm{AD}$ patients. In addition, the Semantic Index now correctly classified $90 \%$ of FTD and $\mathrm{AD}$ patients. These unique patterns of fluency deficits may be indicative of differences in the relative contribution of frontal lobe-mediated retrieval deficits and temporal lobe-mediated semantic deficits in FTLD and AD, respectively.

Taken together, the results of these studies indicate that distinct cognitive profiles are associated with FTLD and AD and suggest that they might aid in differentiating between the two diseases. This conclusion is supported by several other studies using clinically diagnosed patients that found similar levels of discriminability when differentiating FTD from AD on the basis of tests of executive function, visuospatial abilities, and episodic memory (Elfgren et al. 1994; Gregory et al. 1997; Lipton et al. 2005; Libon et al. 2007). These differences are robust enough to be detected with relatively brief dementiascreening instruments that tap multiple cognitive functions (Mathuranath et al. 2000; Bier et al. 2004; Slachevsky et al. 2004).

\section{Alzheimer Disease versus Vascular Dementia}

$\mathrm{VaD}$ refers to a cumulative decline in cognitive functioning secondary to multiple or strategically placed infarctions, ischemic injury, or hemorrhagic lesions (for review, see Wetzel and Kramer 2008). Research diagnostic criteria for $\mathrm{VaD}$ require that multiple cognitive deficits occur in the presence of focal neurological signs 
S. Weintraub et al.

and symptoms and/or laboratory (e.g., CT or MRI scan) evidence of cerebrovascular disease that is thought to be etiologically related to the cognitive impairment (Chui et al. 1992; Roman et al. 1993). A relationship between dementia and cerebrovascular disease is often indicated if the onset of dementia occurs within several months of a recognized stroke, there is an abrupt deterioration in cognitive functioning, or the course of cognitive deterioration is fluctuating or stepwise. The clinical and neuropathologic presentation of $\mathrm{VaD}$ is quite heterogeneous and can include multi-infarct dementia (MID) associated with multiple large cortical infarctions, dementia due to strategically placed infarction, and subcortical ischemic vascular dementia due to subcortical small vessel disease that results in multiple lacunar strokes, leukoaraiosis, or diffuse white matter pathology (Hodges and Graham 2001).
Neuropsychological studies largely show that patients with $\mathrm{VaD}$ are more impaired than those with $\mathrm{AD}$ on tests of executive functions, whereas patients with $\mathrm{AD}$ are more impaired than those with $\mathrm{VaD}$ on tests of episodic memory (particularly delayed recall) (Desmond et al. 1999; Graham et al. 2004; Reed et al. 2007). Executive dysfunction is often the most prominent deficit in $\mathrm{VaD}$, perhaps because white matter pathology (particularly in subcortical ischemic vascular dementia) interrupts fronto-subcortical networks that mediate this aspect of cognition. Consistent with this possibility, Price et al. (2005) showed that $\mathrm{VaD}$ patients with significant white matter abnormality on imaging exhibited greater executive dysfunction and visuoconstructional impairment than memory and language impairment (see also Mathias and Burke 2009, for review).

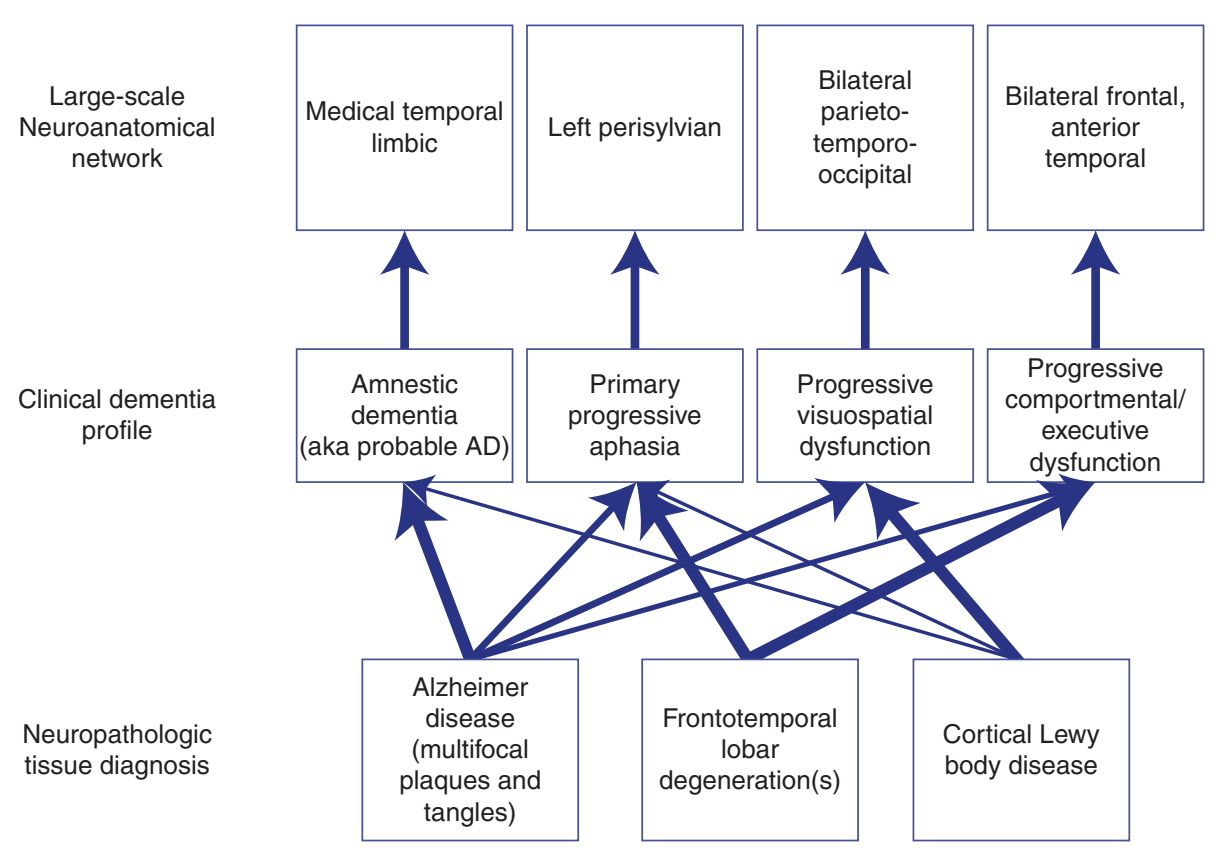

Figure 1. The neuropsychological profiles of dementia reflect the impact of disease on distinctive neuroanatomic networks associated with complex cognitive domains. For example, prominent amnesia is associated with medial temporal dysfunction, whereas aphasia is a consequence of left perisylvian dysfunction. The relationship between clinical symptoms and underlying neuropathology, however, is less straightforward, as indicated by the multiple neuropathologic diagnoses associated with the various clinical dementia syndromes. The thickness of the lines connecting the clinical and neuropathologic levels represents the strength of associations between them (Mesulam 2000). 
The Neuropsychological Profile of Alzheimer Disease
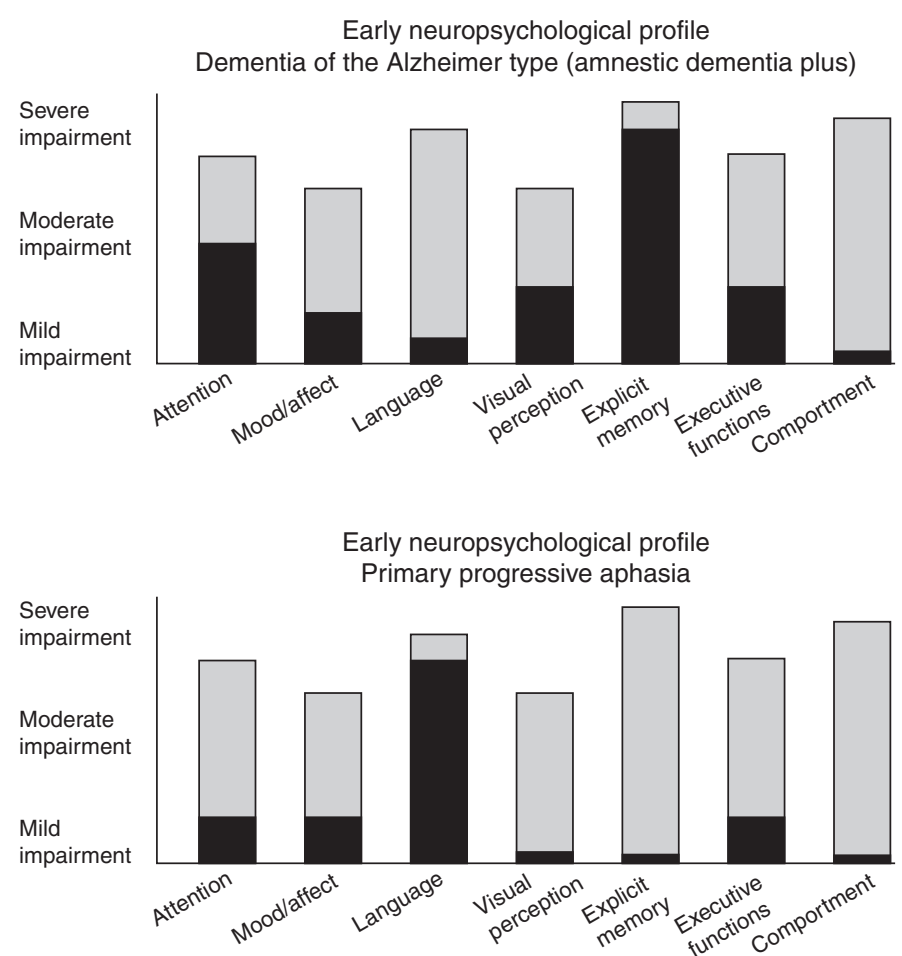

Early neuropsychological profile Behavioral variant FTD

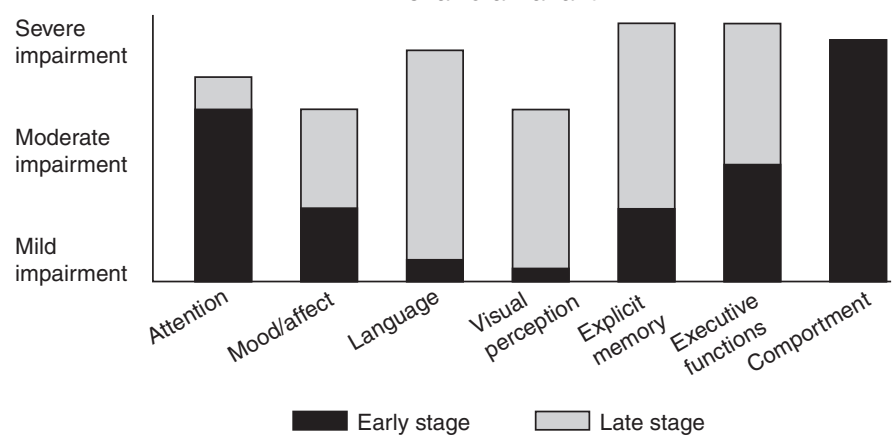

Figure 2. Three graphs, each schematically representing early- and late-stage cognitive/behavioral profiles of three neuropsychologically distinct dementia syndromes. The height of the bars represents the level of impairment: mild, moderate, or severe. In late stages of any dementia syndrome (represented by gray bars) cognitive functions are similarly impaired in an undifferentiated manner and it is difficult to pinpoint one single domain that characterizes the syndrome. However, in early stages, represented by black bars, it is possible to differentiate among domains that are unimpaired or mildly impaired and those that are distinctly abnormal. The most typical early cognitive profile of dementia of the Alzheimer type is one of a prominent amnesia with additional cognitive deficits ("plus"; top graph); in primary progressive aphasia, the early stages are marked by salient language deficits in relative isolation (middle graph); in behavioral variant frontotemporal dementia, the most salient findings in early stages are in the domains of comportment and executive functions (bottom graph). 
S. Weintraub et al.

Unfortunately, cognitive measures appear to be limited in their ability to effectively discriminate between $\mathrm{VaD}$ and $\mathrm{AD}$ (Mathias and Burke 2009). When neuropsychological profiles were compared in patients with autopsy-confirmed $\mathrm{VaD}$ or $\mathrm{AD}$, only $45 \%$ of $\mathrm{VaD}$ patients exhibited a profile with more prominent executive dysfunction than memory impairment, and $71 \%$ of $\mathrm{AD}$ patients exhibited a profile with memory impairment more prominent than executive dysfunction (Reed et al. 2007). Studies based on clinically diagnosed groups are even more likely to be inconclusive because of the overlap in the pathology of $\mathrm{AD}$ and $\mathrm{VaD}$. Schneider and colleagues (2007), for example, found that $38 \%$ of 50 demented patients who came to autopsy had pathological AD plus infarctions, whereas $30 \%$ had $\mathrm{AD}$ pathology alone. Vascular pathology increased the odds of dementia and exacerbated memory dysfunction in those with AD.

\section{CONCLUSIONS}

Neuropsychology has contributed importantly to the characterization of the dementia associated with the neuropathology of $\mathrm{AD}$, its differentiation from cognitive changes accompanying normal aging, and its distinction from dementias associated with other types of neuropathology. The neuropsychological study of AD has advanced our understanding of other diseases that cause dementia, including cortical Lewy body disease, cerebrovascular disease, and FTLD. The very earliest neuropsychological symptoms of a dementia reflect the neuroanatomical systems that bear the load of the associated pathology but the relationship between the symptoms and underlying disease is less obvious (Fig. 1). Amnestic dementia has the highest likelihood of being associated with $\mathrm{AD}$ pathology, but early aphasia, progressive visuospatial deficits, and changes in personality can also be associated with $\mathrm{AD}$ neuropathology. As dementia progresses from early to late stages, symptom domain boundaries become blurred and distinctive profiles are difficult to discern (Fig. 2). Thus, neuropsychological profiles are most informative in early stages. The development of fluid and neuroimaging biomarkers will no doubt improve diagnosis and ultimately be used to measure treatment effects. However, neuropsychological characterization remains essential to understanding the individual patient's deficits so that nonpharmacologic interventions can be appropriately applied and so that patient and caregiver educational materials are appropriately targeted (Weintraub and Morhardt 2005).

\section{ACKNOWLEDGMENTS}

The authors wish to acknowledge the following grants: AG13854 (Northwestern Alzheimer's Disease Core Center) and AG05131 (University of California San Diego Alzheimer's Disease Research Center), both from the National Institute on Aging.

\section{REFERENCES}

Albert MS. 1996. Cognitive and neurobiologic markers of early Alzheimer disease. Proc Natl Acad Sci 93: 1354713551.

Albert MS, Blacker D. 2006. Mild cognitive impairment and dementia. Annu Rev Clin Psychol 2: 379-388.

Albert MS, Dekosky ST, Dickson D, Dubois B, Feldman HH, Fox NC, Gamst A, Holtzman DM, Jagust WJ, Petersen RC, et al. 2011. The diagnosis of mild cognitive impairment due to Alzheimer's disease: Recommendations from the National Institute on Aging-Alzheimer's Association workgroups on diagnostic guidelines for Alzheimer's disease. Alzheimers Dement 7: 270-279.

Aronoff JM, Gonnerman LM, Almor A, Arunachalam S, Kempler D, Andersen ES. 2006. Information content versus relational knowledge: Semantic deficits in patients with Alzheimer's disease. Neuropsychologia 44: 21-35.

Backman L, Small BJ, Fratiglioni L. 2001. Stability of the preclinical episodic memory deficit in Alzheimer's disease. Brain 124: 96-102.

Baddeley A. 2003. Working memory: Looking back and looking forward. Nat Rev Neurosci 4: 829-839.

Baddeley AD, Bressi S, Della Sala S, Logie R, Spinnler H. 1991. The decline of working memory in Alzheimer's disease. A longitudinal study. Brain 114: 2521-2542.

Ball K, Owsley C. 2003. Driving competence: It's not a matter of age. J Am Geriatr Soc 51: 1499-1501.

Ball KK, Beard BL, Roenker DL, Miller RL, Griggs DS. 1988. Age and visual search: Expanding the useful field of view. J Opt Soc Am A 5: 2210-2219.

Barber R, Snowden JS, Craufurd D. 1995. Frontotemporal dementia and Alzheimer's disease: Retrospective 
differentiation using information from informants. $J$ Neurol Neurosurg Psychiatry 59: 61-70.

Barber PA, Varma AR, Lloyd JJ, Haworth B, Snowden JS, Neary D. 2000. The electroencephalogram in dementia with Lewy bodies. Acta Neurol Scand 101: 53-56.

Bayles KA. 1982. Language function in senile dementia. Brain Lang 16: 265-280.

Bayles KA, Tomoeda CK. 1983. Confrontation naming impairment in dementia. Brain Lang 19: 98-114.

Becker JA, Hedden T, Carmasin J, Maye J, Rentz DM, Putcha D, Fischl B, Greve DN, Marshall GA, Salloway S, et al. 2010. Amyloid- $\beta$ associated cortical thinning in clinically normal elderly. Ann Neurol 69: 1032-1042.

Bier JC, Ventura M, Donckels V, Van Eyll E, Claes T, Slama H, Fery P, Vokaer M, Pandolfo M. 2004. Is the Addenbrooke's cognitive examination effective to detect frontotemporal dementia? J Neurol 251: 428-431.

Binetti G, Cappa SF, Magni E, Padovani A, Bianchetti A, Trabucchi M. 1996. Disorders of visual and spatial perception in the early stage of Alzheimer's disease. Ann NY Acad Sci 777: 221-225.

Blair M, Marczinski CA, Davis-Faroque N, Kertesz A. 2007. A longitudinal study of language decline in Alzheimer's disease and frontotemporal dementia. J Int Neuropsychol Soc 13: $237-245$.

Bondi MW, Monsch AU, Butters N, Salmon DP, Paulsen JS. 1993. Utility of a modified version of the Wisconsin Card Sorting Test in the detection of dementia of the Alzheimer type. Clin Neuropsychol 7: 161-170.

Bondi MW, Monsch AU, Galasko D, Butters N, Salmon DP, Delis DC. 1994. Preclinical cognitive markers of dementia of the Alzheimer type. Neuropsychology 8: 374-384.

Bowles NL, Obler LK, Albert ML. 1987. Naming errors in healthy aging and dementia of the Alzheimer type. Cortex 23: 519-524.

Bozeat S, Gregory CA, Ralph MA, Hodges JR. 2000. Which neuropsychiatric and behavioural features distinguish frontal and temporal variants of frontotemporal dementia from Alzheimer's disease? J Neurol Neurosurg Psychiatry 69: $178-186$.

Braak H, Braak E. 1991. Neuropathological staging of Alzheimer-related changes. Acta Neuropathol (Berl) 82: 239-259.

Braak H, Braak E. 1996a. Development of Alzheimer-related neurofibrillary changes in the neocortex inversely recapitulates cortical myelogenesis. Acta Neuropathol (Berl) 92: 197-201.

Braak H, Braak E. 1996b. Evolution of the neuropathology of Alzheimer's disease. Acta Neurol Scand Suppl 165: $3-12$.

Braak E, Arai K, Braak H. 1999. Cerebellar involvement in Pick's disease: Affliction of mossy fibers, monodendritic brush cells, and dentate projection neurons. Exp Neurol 159: $153-163$.

Brun A. 1987. Frontal lobe degeneration of non-Alzheimer type. I. Neuropathology. Arch Gerontol Geriatr 6: $193-$ 208.

Buckner RL, Snyder AZ, Shannon BJ, LaRossa G, Sachs R, Fotenos AF, Sheline YI, Klunk WE, Mathis CA, Morris JC, et al. 2005. Molecular, structural, and functional characterization of Alzheimer's disease: Evidence for a re- lationship between default activity, amyloid, and memory. J Neurosci 25: 7709-7717.

Buckner RL, Andrews-Hanna JR, Schacter DL. 2008. The brain's default network: Anatomy, function, and relevance to disease. Ann NY Acad Sci 1124: 1-38.

Butters N, Granholm E, Salmon DP, Grant I, Wolfe J. 1987. Episodic and semantic memory: A comparison of amnesic and demented patients. J Clin Exp Neuropsychol 9: 479-497.

Butters N, Salmon DP, Cullum CM, Cairns P, Troster AI, Jacobs D, Moss M, Cermak LS. 1988. Differentiation of amnesic and demented patients with the Wechsler memory scale-Revised. Clin Neuropsychol 2: 133-148.

Caine D. 2004. Posterior cortical atrophy: A review of the literature. Neurocase 10: 382-385.

Caycedo AM, Miller B, Kramer J, Rascovsky K. 2009. Early features in frontotemporal dementia. Curr Alzheimer Res 6: 337-340.

Chen P, Ratcliff G, Belle SH, Cauley JA, DeKosky ST, Ganguli M. 2001. Patterns of cognitive decline in presymptomatic Alzheimer disease: A prospective community study. Arch Gen Psychiatry 58: 853-858.

Cherry BJ, Buckwalter JG, Henderson VW. 2002. Better preservation of memory span relative to supraspan immediate recall in Alzheimer's disease. Neuropsychologia 40: 846-852.

Chertkow H, Bub D. 1990. Semantic memory loss in dementia of Alzheimer's type. What do various measures measure? Brain 113: 397-417.

Chui HC, Victoroff JI, Margolin D, Jagust W, Shankle R, Katzman R. 1992. Criteria for the diagnosis of ischemic vascular dementia proposed by the State of California Alzheimer's Disease Diagnostic and Treatment Centers. Neurology 42: 473-480.

Collette F, Van der Linden M, Bechet S, Salmon E. 1999. Phonological loop and central executive functioning in Alzheimer's disease. Neuropsychologia 37: 905-918.

Collie A, Maruff P. 2000. The neuropsychology of preclinical Alzheimer's disease and mild cognitive impairment. Neurosci Biobehav Rev 24: 365-374.

Cronin-Golomb A, Amick M. 2001. Spatial abilities in aging, Alzheimer's disease, and Parkinson's disease. In Handbook of neuropsychology, vol. 6: Aging and dementia, 2nd ed. (ed. Boller F, Cappa S), pp. 119-143. Elsevier, Amsterdam.

Dalla Barba G, Goldblum MC. 1996. The influence of semantic encoding on recognition memory in Alzheimer's disease. Neuropsychologia 34: 1181-1186.

Dalla Barba G, Wong C. 1995. Encoding specificity and intrusion in Alzheimer's disease and amnesia. Brain Cogn 27: 1-16.

Delis DC, Massman PJ, Butters N, Salmon DP, Cermak LS, Kramer JH. 1991. Profiles of demented and amnesic patients on the California verbal learning test: Implications for the assessment of memory disorders. Psychol Assessment 3: 19-26.

Della Sala S, Spinnler H, Trivelli C. 1996. Slowly progressive impairment of spatial exploration and visual perception. Neurocase 2: 299-323.

De Meyer G, Shapiro F, Vanderstichele H, Vanmechelen E, Engelborghs S, De Deyn PP, Coart E, Hansson O, 
S. Weintraub et al.

Minthon L, Zetterberg H, et al. 2010. Diagnosisindependent Alzheimer disease biomarker signature in cognitively normal elderly people. Arch Neurol 67: 949-956.

Desmond DW, Erkinjuntti T, Sano M, Cummings JL, Bowler JV, Pasquier F, Moroney JT, Ferris SH, Stern Y, Sachdev PS, et al. 1999. The cognitive syndrome of vascular dementia: Implications for clinical trials. Alzheimer Dis Assoc Disord 13 (Suppl 3): S21-S29.

de Toledo-Morrell L, Goncharova I, Dickerson B, Wilson RS, Bennett DA. 2000. From healthy aging to early Alzheimer's disease: In vivo detection of entorhinal cortex atrophy. Ann NY Acad Sci 911: 240-253.

Dubois B, Feldman HH, Jacova C, Dekosky ST, BarbergerGateau P, Cummings J, Delacourte A, Galasko D, Gauthier S, Jicha G, et al. 2007. Research criteria for the diagnosis of Alzheimer's disease: Revising the NINCDS-ADRDA criteria. Lancet Neurol 6: 734-746.

Elfgren C, Brun A, Gustafson L, Johanson A, Minthon L, Passant U, Risberg J. 1994. Neuropsychological tests as discriminators between dementia of Alzheimer's type and frontotemporal dementia. Int $J$ Geriatr Psychiatry 9: $635-642$.

Ferman TJ, Smith GE, Boeve BF, Graff-Radford NR, Lucas JA, Knopman DS, Petersen RC, Ivnik RJ, Wszolek Z, Uitti R, et al. 2006. Neuropsychological differentiation of dementia with Lewy bodies from normal aging and Alzheimer's disease. Clin Neuropsychol 20: 623-636.

Festa EK, Insler RZ, Salmon DP, Paxton J, Hamilton JM, Heindel WC. 2005. Neocortical disconnectivity disrupts sensory integration in Alzheimer's disease. Neuropsychology 19: $728-738$.

Flicker C, Bartus RT, Crook TH, Ferris SH. 1984. Effects of aging and dementia upon recent visuospatial memory. Neurobiol Aging 5: 275-283.

Foster NL, Chase TN, Fedio P, Patronas NJ, Brooks RA, Di Chiro G. 1983. Alzheimer's disease: Focal cortical changes shown by positron emission tomography. $\mathrm{Neu}$ rology 33: 961-965.

Foster JK, Behrmann M, Stuss DT. 1999. Visual attention deficits in Alzheimer's disease: Simple versus conjoined feature search. Neuropsychology 13: 223-245.

Fuld PA, Katzman R, Davies P, Terry RD. 1982. Intrusions as a sign of Alzheimer dementia: Chemical and pathological verification. Ann Neurol 11: 155-159.

Gliebus G, Bigio E, Caplan D, Mesulam M, Geula C. 2009. Phenotypically concordant TDP-43 neuroanatomy in the PPA3 family with progranulin mutation. Soc Neurosci Abstr Online. 434437/L431.

Gomez-Tortosa E, Irizarry MC, Gomez-Isla T, Hyman BT. 2000. Clinical and neuropathological correlates of dementia with Lewy bodies. Ann NYAcad Sci 920: 9-15.

Gorno-Tempini ML, Dronkers NF, Rankin KP, Ogar JM, Phengrasamy L, Rosen HJ, Johnson JK, Weiner MW, Miller BL. 2004. Cognition and anatomy in three variants of primary progressive aphasia. Ann Neurol 55: 335-346.

Gorno-Tempini ML, Hillis AE, Weintraub S, Kertesz A, Mendez M, Cappa SF, Ogar JM, Rohrer JD, Black S, Boeve $\mathrm{BF}$, et al. 2011. Classification of primary progressive aphasia and its variants. Neurology 76: 1006-1014.
Grady CL, Haxby JV, Horwitz B, Sundaram M, Berg G, Schapiro M, Friedland RP, Rapoport SI. 1988. Longitudinal study of the early neuropsychological and cerebral metabolic changes in dementia of the Alzheimer type. J Clin Exp Neuropsychol 10: 576-596.

Graham NL, Emery T, Hodges JR. 2004. Distinctive cognitive profiles in Alzheimer's disease and subcortical vascular dementia. J Neurol Neurosurg Psychiatry 75: 61-71.

Greenwood PM, Parasuraman R. 1997. Attention in aging and Alzheimer's disease: Behavior and neural systems. In Attention, development, and psychopathology (ed. Burback JA, Enns JT, et al.), pp. 288-317. Guildford Press, New York.

Greenwood PM, Parasuraman R, Alexander GE. 1997. Controlling the focus of spatial attention during visual search: Effects of advanced aging and Alzheimer disease. Neuropsychology 11: 3-12.

Gregory CA, Orrell M, Sahakian B, Hodges JR. 1997. Can frontotemporal dementia and Alzheimer's disease be differentiated using a brief battery of tests? Int J Geriatr Psychiatry 12: 375-383.

Grober E, Kawas C. 1997. Learning and retention in preclinical and early Alzheimer's disease. Psychol Aging 12: $183-188$.

Grossman M. 2010. Primary progressive aphasia: Clinicopathological correlations. Nat Rev Neurol 6: 88-97.

Grossman M, Mickanin J, Onishi K, Hughes E. 1996. Verb comprehension deficits in probable Alzheimer's disease. Brain Lang 53: 369-389.

Grossman M, Libon DJ, Forman MS, Massimo L, Wood E, Moore P, Anderson C, Farmer J, Chatterjee A, Clark $\mathrm{CM}$, et al. 2007. Distinct antemortem profiles in patients with pathologically defined frontotemporal dementia. Arch Neurol 64: 1601-1609.

Guidi M, Paciaroni L, Paolini S, De Padova S, Scarpino O. 2006. Differences and similarities in the neuropsychological profile of dementia with Lewy bodies and Alzheimer's disease in the early stage. J Neurol Sci 248: 120-123.

Gustafson L. 1987. Frontal lobe degeneration of nonAlzheimer type. II. Clinical picture and differential diagnosis. Arch Gerontol Geriatr 6: 209-223.

Hamilton JM, Salmon DP, Galasko D, Delis DC, Hansen LA, Masliah E, Thomas RG, Thal LJ. 2004. A comparison of episodic memory deficits in neuropathologically-confirmed dementia with Lewy bodies and Alzheimer's disease. J Int Neuropsychol Soc 10: 689-697.

Hamilton JM, Salmon DP, Galasko D, Raman R, Emond J, Hansen LA, Masliah E, Thal LJ. 2008. Visuospatial deficits predict rate of cognitive decline in autopsy-verified dementia with Lewy bodies. Neuropsychology 22: 729 737.

Hansen L, Salmon D, Galasko D, Masliah E, Katzman R, DeTeresa R, Thal L, Pay MM, Hofstetter R, Klauber M, et al. 1990. The Lewy body variant of Alzheimer's disease: A clinical and pathologic entity. Neurology 40: 1-8.

Henry JD, Crawford JR, Phillips LH. 2004. Verbal fluency performance in dementia of the Alzheimer's type: A meta-analysis. Neuropsychologia 42: 1212-1222.

Henry JD, Crawford JR, Phillips LH. 2005. A meta-analytic review of verbal fluency deficits in Huntington's disease. Neuropsychology 19: 243-252. 
Higuchi M, Tashiro M, Arai H, Okamura N, Hara S, Higuch S, Itoh M, Shin RW, Trojanowski JQ, Sasaki H. 2000. Glucose hypometabolism and neuropathological correlates in brains of dementia with Lewy bodies. Exp Neurol 162: $247-256$.

Hillis AE, Oh S, Ken L. 2004. Deterioration of naming nouns versus verbs in primary progressive aphasia. Ann Neurol 55: $268-275$.

Hodges JR, Graham NL. 2001. Vascular dementias. In Early onset dementia: A multidisciplinary approach (ed. Hodges JR), pp. 319-337. Oxford University Press, Oxford.

Hodges JR, Patterson K. 1995. Is semantic memory consistently impaired early in the course of Alzheimer's disease? Neuroanatomical and diagnostic implications. Neuropsychologia 33: 441-459.

Hodges JR, Patterson K. 2007. Semantic dementia: A unique clinicopathological syndrome. Lancet Neurol 6: 10041014.

Hodges JR, Salmon DP, Butters N. 1991. The nature of the naming deficit in Alzheimer's and Huntington's disease. Brain 114: 1547-1558.

Hodges JR, Salmon DP, Butters N. 1992. Semantic memory impairment in Alzheimer's disease: Failure of access or degraded knowledge? Neuropsychologia 30: 301-314.

Hof PR, Archin N, Osmand AP, Dougherty JH, Wells C, Bouras C, Morrison JH. 1993. Posterior cortical atrophy in Alzheimer's disease: Analysis of a new case and re-evaluation of a historical report. Acta Neuropathol 86: $215-223$.

Hof PR, Vogt BA, Bouras C, Morrison JH. 1997. Atypical form of Alzheimer's disease with prominent posterior cortical atrophy: A review of lesion distribution and circuit disconnection in cortical visual pathways. Vision Res 37: 3609-3625.

Holm IE, Englund E, Mackenzie IR, Johannsen P, Isaacs AM. 2007. A reassessment of the neuropathology of frontotemporal dementia linked to chromosome 3. J Neuropathol Exp Neurol 66: 884-891.

Howieson DB, Dame A, Camicioli R, Sexton G, Payami H, Kaye JA. 1997. Cognitive markers preceding Alzheimer's dementia in the healthy oldest old. J Am Geriatr Soc 45: 584-589.

Ince PG, Perry EK, Morris CM. 1998. Dementia with Lewy bodies. A distinct non-Alzheimer dementia syndrome? Brain Pathol 8: 299-324.

Jack CR Jr, Petersen RC, Xu YC, Waring SC, O'Brien PC, Tangalos EG, Smith GE, Ivnik RJ, Kokmen E. 1997. Medial temporal atrophy on MRI in normal aging and very mild Alzheimer's disease. Neurology 49: 786-794.

Jack CR Jr, Petersen RC, Xu Y, O'Brien PC, Smith GE, Ivnik RJ, Boeve BF, Tangalos EG, Kokmen E. 2000. Rates of hippocampal atrophy correlate with change in clinical status in aging and AD. Neurology 55: 484-489.

Jack CR Jr, Knopman DS, Jagust WJ, Shaw LM, Aisen PS, Weiner MW, Petersen RC, Trojanowski JQ. 2010. Hypothetical model of dynamic biomarkers of the Alzheimer's pathological cascade. Lancet Neurol 9: 119-128.

Jacobs D, Salmon DP, Tröster AI, Butters N. 1990. Intrusion errors in the figural memory of patients with Alzheimer's and Huntington's disease. Arch Clin Neuropsychol 5: $49-57$.
Jacobs DM, Sano M, Dooneief G, Marder K, Bell KL, Stern Y. 1995. Neuropsychological detection and characterization of preclinical Alzheimer's disease [comment]. Neurology 45: $957-962$.

Johnson JK, Head E, Kim R, Starr A, Cotman CW. 1999. Clinical and pathological evidence for a frontal variant of Alzheimer disease. Arch Neurol 56: 1233-1239.

Johnson DK, Morris JC, Galvin JE. 2005. Verbal and visuospatial deficits in dementia with Lewy bodies. Neurology 65: $1232-1238$.

Johnson DK, Storandt M, Morris JC, Galvin JE. 2009. Longitudinal study of the transition from healthy aging to Alzheimer disease. Arch Neurol 66: 1254-1259.

Kawas CH, Corrada MM, Brookmeyer R, Morrison A, Resnick SM, Zonderman AB, Arenberg D. 2003. Visual memory predicts Alzheimer's disease more than a decade before diagnosis. Neurology 60: 1089-1093.

Kertesz A, Nadkarni N, Davidson W, Thomas AW. 2000. The Frontal Behavioral Inventory in the differential diagnosis of frontotemporal dementia. J Int Neuropsychol Soc 6: $460-468$.

Kim M, Thompson CK. 2004. Verb deficits in Alzheimer's disease and agrammatism: Implications for lexical organization. Brain Lang 88: 1-20.

Knopman DS, Ryberg S. 1989. A verbal memory test with high predictive accuracy for dementia of the Alzheimer type. Arch Neurol 46: 141-145.

Knopman DS, Mastri AR, Frey WH 2nd, Sung JH, Rustan T 1990. Dementia lacking distinctive histologic features: A common non-Alzheimer degenerative dementia. Neurology 40: 251-256.

Knopman DS, Jack CR Jr, Kramer JH, Boeve BF, Caselli RJ, Graff-Radford NR, Mendez MF, Miller BL, Mercaldo ND. 2009. Brain and ventricular volumetric changes in frontotemporal lobar degeneration over 1 year. Neurology 72: $1843-1849$.

Kramer JH, Jurik J, Sha SJ, Rankin KP, Rosen HJ, Johnson JK, Miller BL. 2003. Distinctive neuropsychological patterns in frontotemporal dementia, semantic dementia, and Alzheimer disease. Cogn Behav Neurol 16: 211-218.

Kraybill ML, Larson EB, Tsuang DW, Teri L, McCormick WC, Bowen JD, Kukull WA, Leverenz JB, Cherrier MM. 2005. Cognitive differences in dementia patients with autopsy-verified AD, Lewy body pathology, or both. Neurology 64: 2069-2073.

Lange KW, Sahakian BJ, Quinn NP, Marsden CD, Robbins TW. 1995. Comparison of executive and visuospatial memory function in Huntington's disease and dementia of Alzheimer type matched for degree of dementia. J Neurol Neurosurg Psych 58: 598-606.

Lange KL, Bondi MW, Salmon DP, Galasko D, Delis DC, Thomas RG, Thal LJ. 2002. Decline in verbal memory during preclinical Alzheimer's disease: Examination of the effect of APOE genotype. J Int Neuropsychol Soc 8: 943-955.

Lefleche G, Albert MS. 1995. Executive function deficits in mild Alzheimer's disease. Neuropsychology 9: 313-320.

Libon DJ, Xie SX, Moore P, Farmer J, Antani S, McCawley G, Cross K, Grossman M. 2007. Patterns of neuropsychological impairment in frontotemporal dementia. Neurology 68: 369-375. 
S. Weintraub et al.

Linn RT, Wolf PA, Bachman DL, Knoefel JE, Cobb JL, Belanger AJ, Kaplan EF, D’Agostino RB. 1995. The "preclinical phase" of probable Alzheimer's disease. A 13-year prospective study of the Framingham cohort. Arch Neurol 52: $485-490$.

Lipton AM, Ohman KA, Womack KB, Hynan LS, Ninman ET, Lacritz LH. 2005. Subscores of the FAB differentiate frontotemporal lobar degeneration from AD. Neurology 65: 726-731.

Locascio JJ, Growdon JH, Corkin S. 1995. Cognitive test performance in detecting, staging, and tracking Alzheimer's disease. Arch Neurol 52: 1087-1099.

Mackenzie IR, Neumann M, Bigio EH, Cairns NJ, Alafuzoff I, Kril J, Kovacs GG, Ghetti B, Halliday G, Holm IE, et al. 2010. Nomenclature and nosology for neuropathologic subtypes of frontotemporal lobar degeneration: An update. Acta Neuropathol 119: 1-4.

Mapstone M, Steffenella TM, Duffy CJ. 2003. A visuospatial variant of mild cognitive impairment: getting lost between aging and AD. Neurology 60: 802-808.

Martin A, Fedio P. 1983. Word production and comprehension in Alzheimer's disease: The breakdown of semantic knowledge. Brain Lang 19: 124-141.

Martin A, Brouwers P, Cox C, Fedio P. 1985. On the nature of the verbal memory deficit in Alzheimer's disease. Brain Lang 25: 323-341.

Mathias JL, Burke J. 2009. Cognitive functioning in Alzheimer's and vascular dementia: A meta-analysis. Neuropsychology 23: 411-423.

Mathuranath PS, Nestor PJ, Berrios GE, Rakowicz W, Hodges JR. 2000. A brief cognitive test battery to differentiate Alzheimer's disease and frontotemporal dementia. Neurology 55: 1613-1620.

McKeith IG, Dickson DW, Lowe J, Emre M, O'Brien JT, Feldman H, Cummings J, Duda JE, Lippa C, Perry EK, et al. 2005. Diagnosis and management of dementia with Lewy bodies: Third report of the DLB Consortium. Neurology 65: $1863-1872$.

McKhann G, Drachman D, Folstein M, Katzman R, Price D, Stadlan E. 1984. Clinical diagnosis of Alzheimer's disease: Report of the NINCDS-ADRDA Work Group under the auspices of Department of Health and Human Services Task Force on Alzheimer's Disease. Neurology 34: 939-944.

McKhann GM, Knopman DS, Chertkow H, Hyman BT, Jack CR Jr, Kawas CH, Klunk WE, Koroshetz WJ, Manly JJ, Mayeux R, et al. 2011. The diagnosis of dementia due to Alzheimer's disease: Recommendations from the National Institute on Aging-Alzheimer's Association workgroups on diagnostic guidelines for Alzheimer's disease. Alzheimers Dement 7: 263-269.

Mendez MF, Cherrier M, Perryman KM, Pachana N, Miller BL, Cummings JL. 1996. Frontotemporal dementia versus Alzheimer's disease: Differential cognitive features. Neurology 47: 1189-1194.

Mendez MF, Perryman KM, Miller BL, Cummings JL. 1998. Behavioral differences between frontotemporal dementia and Alzheimer's disease: A comparison on the BEHAVE-AD rating scale. Int Psychogeriatr 10: $155-162$.

Merdes AR, Hansen LA, Jeste DV, Galasko D, Hofstetter CR, Ho GJ, Thal LJ, Corey-Bloom J. 2003. Influence of
Alzheimer pathology on clinical diagnostic accuracy in dementia with Lewy bodies. Neurology 60: 1586-1590.

Mesulam M. 1982. Slowly progressive aphasia without generalized dementia. Ann Neurol 11: 592-598.

Mesulam M-M. 2000. Aging, Alzheimer's disease, and dementia: Clinical and neurobiological perspectives. In Principles of cognitive and behavioral neurology, 2nd ed. (ed. Mesulam M-M), pp. 439-522. Oxford University Press, New York.

Mesulam M. 2001. Primary progressive aphasia. Ann Neurol 49: $425-432$.

Mesulam M. 2003. Primary progressive aphasia-A language-based dementia. N Engl J Med 349: 1535-1542.

Mesulam M. 2008. Primary progressive aphasia pathology. Ann Neurol 63: 124-125.

Mesulam M, Wicklund A, Johnson N, Rogalski E, Leger GC, Rademaker A, Weintraub S, Bigio EH. 2008. Alzheimer and frontotemporal pathology in subsets of primary progressive aphasia. Ann Neurol 63: 709-719.

Mesulam M, Wieneke C, Rogalski E, Cobia D, Thompson CK, Weintraub S. 2009. Quantitative template for subtyping primary progressive aphasia. Arch Neurol 66: $1545-1551$.

Miller BL, Ikonte C, Ponton M, Levy M, Boone K, Darby A, Berman N, Mena I, Cummings JL. 1997. A study of the Lund-Manchester research criteria for frontotemporal dementia: Clinical and single-photon emission CT correlations. Neurology 48: 937-942.

Minoshima S, Foster NL, Sima AA, Frey KA, Albin RL, Kuhl DE. 2001. Alzheimer's disease versus dementia with Lewy bodies: Cerebral metabolic distinction with autopsy confirmation. Ann Neurol 50: 358-365.

Mintun MA, Larossa GN, Sheline YI, Dence CS, Lee SY, Mach RH, Klunk WE, Mathis CA, DeKosky ST, Morris JC. 2006. [11C]PIB in a nondemented population: Potential antecedent marker of Alzheimer disease. Neurology 67: 446-452.

Monsch AU, Bondi MW, Butters N, Salmon DP, Katzman R, Thal LJ. 1992. Comparisons of verbal fluency tasks in the detection of dementia of the Alzheimer type. Arch Neurol 49: $1253-1258$.

Moonis M, Swearer JM, Dayaw MP, St George-Hyslop P, Rogaeva E, Kawarai T, Pollen DA. 2005. Familial Alzheimer disease: Decreases in CSF A 342 levels precede cognitive decline. Neurology 65: 323-325.

Morris JC, Heyman A, Mohs RC, Hughes JP, van Belle G, Fillenbaum G, Mellits ED, Clark C. 1989. The Consortium to Establish a Registry for Alzheimer's Disease (CERAD). Part I. Clinical and neuropsychological assessment of Alzheimer's disease. Neurology 39: 1159-1165.

Morris JC, Storandt M, McKeel DW Jr, Rubin EH, Price JL Grant EA, Berg L. 1996. Cerebral amyloid deposition and diffuse plaques in "normal" aging: Evidence for presymptomatic and very mild Alzheimer's disease. Neurology 46: $707-719$.

Morrison JH, Hof PR, Bouras C. 1991. An anatomic substrate for visual disconnection in Alzheimer's disease. Ann NY Acad Sci 640: 36-43.

Neary D, Snowden J. 1996. Fronto-temporal dementia: Nosology, neuropsychology, and neuropathology. Brain $\operatorname{Cogn}$ 31: 176-187. 
Neary D, Brun A, Englund B, Gustafson L, Passant U, Mann DMA, Snowden JS. 1994. Clinical and neuropathological criteria for frontotemporal dementia. J Neurol Neurosurg Psychiatry 57: 416-418.

Neary D, Snowden JS, Gustafson L, Passant U, Stuss D, Black S, Freedman M, Kertesz A, Robert PH, Albert M, et al. 1998. Frontotemporal lobar degeneration: A consensus on clinical diagnostic criteria. Neurology 51: 1546-1554.

Nebes RD. 1989. Semantic memory in Alzheimer's disease. Psychol Bull 106: 377-394.

Nestor PJ, Caine D, Fryer TD, Clarke J, Hodges JR. 2003. The topography of metabolic deficits in posterior cortical atrophy (the visual variant of Alzheimer's disease) with FDG-PET. J Neurol Neurosurg Psychiatry 74: 1521-1529.

Pachana NA, Boone KB, Miller BL, Cummings JL, Berman N. 1996. Comparison of neuropsychological functioning in Alzheimer's disease and frontotemporal dementia. J Int Neuropsychol Soc 2: 505-510.

Parasuraman R, Greenwood PM. 1998. Selective attention in aging and dementia. In The attentive brain (ed. Parasuraman R), pp. 461-487. MIT Press, Cambridge, MA.

Parasuraman R, Haxby JV. 1993. Attention and brain function in Alzheimer's disease: A review. Neuropsychology 7: $242-272$.

Parasuraman R, Greenwood PM, Alexander GE. 1995. Selective impairment of spatial attention during visual search in Alzheimer's disease. Neuroreport 6: 1861-1864.

Parasuraman R, Greenwood PM, Alexander GE. 2000. Alzheimer disease constricts the dynamic range of spatial attention in visual search. Neuropsychologia 38: 11261135.

Perrin RJ, Fagan AM, Holtzman DM. 2009. Multimodal techniques for diagnosis and prognosis of Alzheimer's disease. Nature 461: 916-922.

Perry RJ, Hodges JR. 1999. Attention and executive deficits in Alzheimer's disease. A critical review. Brain 122: 383-404.

Petersen RC, Doody R, Kurz A, Mohs RC, Morris JC, Rabins PV, Ritchie K, Rossor M, Thal L, Winblad B. 2001. Current concepts in mild cognitive impairment. Arch Neurol 58: 1985-1992.

Price CC, Jefferson AL, Merino JG, Heilman KM, Libon DJ 2005. Subcortical vascular dementia: Integrating neuropsychological and neuroradiologic data. Neurology 65: 376-382.

Rabinovici GD, Rascovsky K, Miller BL. 2008. Frontotemporal lobar degeneration: Clinical and pathologic overview. Handb Clin Neurol 89: 343-364.

Rascovsky K, Salmon DP, Ho GJ, Galasko D, Peavy GM, Hansen LA, Thal LJ. 2002. Cognitive profiles differ in autopsy-confirmed frontotemporal dementia and $\mathrm{AD}$. Neurology 58: 1801-1808.

Rascovsky K, Hodges JR, Kipps CM, Johnson JK, Seeley WW, Mendez MF, Knopman D, Kertesz A, Mesulam M, Salmon DP, et al. 2007a. Diagnostic criteria for the behavioral variant of frontotemporal dementia (bvFTD): Current limitations and future directions. Alzheimer Dis Assoc Disord 21.

Rascovsky K, Salmon DP, Hansen LA, Thal LJ, Galasko D. 2007b. Disparate letter and semantic category fluency deficits in autopsy-confirmed frontotemporal dementia and Alzheimer's disease. Neuropsychology 21: 20-30.

Rascovsky K, Hodges JR, Knopman D, Mendez MF, Kramer JH, Neuhaus J, van Swieten JC, Seelaar H, Dopper EGP, Onyike CU, et al. 2011. Sensitivity of revised diagnostic criteria for the behavioral variant of frontotemporal dementia. Brain 134: 2456-2477.

Reed BR, Mungas DM, Kramer JH, Ellis W, Vinters HV, Zarow C, Jagust WJ, Chui HC. 2007. Profiles of neuropsychological impairment in autopsy-defined Alzheimer's disease and cerebrovascular disease. Brain 130: 731-739.

Reiman EM, Caselli RJ, Yun LS, Chen K, Bandy D, Minoshima S, Thibodeau SN, Osborne D. 1996. Preclinical evidence of Alzheimer's disease in persons homozygous for the epsilon 4 allele for apolipoprotein E [see comments]. New Engl J Med 334: 752-758.

Renner JA, Burns JM, Hou CE, McKeel DW Jr, Storandt M, Morris JC. 2004. Progressive posterior cortical dysfunction: A clinicopathologic series. Neurology 63: 1175-1180.

Rizzo M, Reinach S, McGehee D, Dawson J. 1997. Simulated car crashes and crash predictors in drivers with Alzheimer disease. Arch Neurol 54: 545-551.

Rohrer D, Wixted JT, Salmon DP, Butters N. 1995. Retrieval from semantic memory and its implications for Alzheimer's disease. J Exp Psychol Learn Mem Cogn 21: 1127-1139.

Rohrer D, Salmon DP, Wixted JT, Paulsen JS. 1999. The disparate effects of Alzheimer's disease and Huntington's disease on semantic memory. Neuropsychology 13: 381-388.

Roman GC, Tatemichi TK, Erkinjuntti T, Cummings JL, Masdeu JC, Garcia JH, Amaducci L, Orgogozo JM, Brun A, Hofman A, et al. 1993. Vascular dementia: Diagnostic criteria for research studies. Report of the NINDS-AIREN International Workshop. Neurology 43: 250-260.

Salmon DP. 2000. Disorders of memory in Alzheimer's disease. In Handbook of neuropsychology, vol. 2: Memory and its disorders, 2nd ed. (ed. Cermak LS), pp. 155-195. Elsevier, Amsterdam.

Salmon DP, Bondi MW. 2009. Neuropsychological assessment of dementia. Annu Rev Psychol 60: 257-282.

Schneider JA, Arvanitakis Z, Bang W, Bennett DA. 2007. Mixed brain pathologies account for most dementia cases in community-dwelling older persons. Neurology 69: 2197-2204.

Seeley WW, Crawford RK, Zhou J, Miller BL, Greicius MD. 2009. Neurodegenerative diseases target large-scale human brain networks. Neuron 62: 42-52.

Skibinski G, Parkinson NJ, Brown JM, Chakrabarti L, Lloyd SL, Hummerich H, Nielsen JE, Hodges JR, Spillantini MG, Thusgaard T, et al. 2005. Mutations in the endosomal ESCRTIII-complex subunit CHMP2B in frontotemporal dementia. Nat Genet 37: 806-808.

Slachevsky A, Villalpando JM, Sarazin M, Hahn-Barma V, Pillon B, Dubois B. 2004. Frontal assessment battery and differential diagnosis of frontotemporal dementia and Alzheimer disease. Arch Neurol 61: 1104-1107.

Small BJ, Fratiglioni L, Viitanen M, Winblad B, Backman L. 2000. The course of cognitive impairment in preclinical 
S. Weintraub et al.

Alzheimer disease: Three- and 6-year follow-up of a population-based sample. Arch Neurol 57: 839-844.

Snowden JS, Bathgate D, Varma A, Blackshaw A, Gibbons ZC, Neary D. 2001. Distinct behavioural profiles in frontotemporal dementia and semantic dementia. J Neurol Neurosurg Psychiatry 70: 323-332.

Sonty SP, Mesulam M, Thompson CK, Johnson NA, Weintraub S, Parrish TB, Gitelman DR. 2003. Primary progressive aphasia: PPA and the language network. Ann Neurol 53: 35-49.

Sperling RA, Laviolette PS, O’Keefe K, O’Brien J, Rentz DM, Pihlajamaki M, Marshall G, Hyman BT, Selkoe DJ, Hedden T, et al. 2009. Amyloid deposition is associated with impaired default network function in older persons without dementia. Neuron 63: 178-188.

Sperling RA, Aisen PS, Beckett LA, Bennett DA, Craft S, Fagan AM, Iwatsubo T, Jack CR Jr, Kaye J, Montine TJ, et al. 2011. Toward defining the preclinical stages of Alzheimer's disease: Recommendations from the National Institute on Aging-Alzheimer's Association workgroups on diagnostic guidelines for Alzheimer's disease. Alzheimers Dement 7: 280-292.

Stavitsky K, Brickman AM, Scarmeas N, Torgan RL, Tang MX, Albert M, Brandt J, Blacker D, Stern Y. 2006. The progression of cognition, psychiatric symptoms, and functional abilities in dementia with Lewy bodies and Alzheimer disease. Arch Neurol 63: 1450-1456.

Storandt M. 1991. Neuropsychological assessment in Alzheimer's disease. Exp Aging Res 17: 100-101.

Storandt M, Hill RD. 1989. Very mild senile dementia of the Alzheimer type. II. Psychometric test performance. Arch Neurol 46: 383-386.

Storandt M, Kaskie B, Von Dras DD. 1998. Temporal memory for remote events in healthy aging and dementia. Psychol Aging 13: 4-7.

Tales A, Butler SR, Fossey J, Gilchrist ID, Jones RW, Troscianko T. 2002. Visual search in Alzheimer's disease: A deficiency in processing conjunctions of features. Neuropsychologia 40: 1849-1857.

Tenovuo O, Kemppainen N, Aalto S, Nagren K, Rinne JO. 2008. Posterior cortical atrophy: A rare form of dementia with in vivo evidence of amyloid- $\beta$ accumulation. J Alzheimers Dis 15: 351-355.

Thomas-Anterion C, Jacquin K, Laurent B. 2000. Differential mechanisms of impairment of remote memory in Alzheimer's and frontotemporal dementia. Dement Geriatr Cogn Disord 11: 100-106.

Tiraboschi P, Salmon DP, Hansen LA, Hofstetter RC, Thal LJ, Corey-Bloom J. 2006. What best differentiates Lewy body from Alzheimer's disease in early-stage dementia? Brain 129: 729-735.

Treisman A. 1996. The binding problem. Curr Opin Neurobiol 6: 171-178.

Troster AI, Butters N, Salmon DP, Cullum CM, Jacobs D, Brandt J, White RF. 1993. The diagnostic utility of savings scores: Differentiating Alzheimer's and Huntington's diseases with the logical memory and visual reproduction tests. J Clin Exp Neuropsychol 15: 773-788.
Waltz JA, Knowlton BJ, Holyoak KJ, Boone KB, BackMadruga C, McPherson S, Masterman D, Chow T, Cummings JL, Miller BL. 2004. Relational integration and executive function in Alzheimer's disease. Neuropsychology 18: 296-305.

Watts GD, Wymer J, Kovach MJ, Mehta SG, Mumm S, Darvish D, Pestronk A, Whyte MP, Kimonis VE. 2004. Inclusion body myopathy associated with Paget disease of bone and frontotemporal dementia is caused by mutant valosin-containing protein. Nat Genet 36: 377-381.

Weintraub S, Mesulam M. 1993. Four neuropsychological profiles of dementia. In Handbook of neuropsychology (ed. Boller F, Grafman J). Elsevier, Amsterdam.

Weintraub S, Mesulam M-M. 1996. From neuronal networks to dementia: Four clinical profiles. In La demence: Pourquoi? (ed. Fôret F, Christen Y, Boller F), pp. 75-97. Foundation Nationale de Gerontologie, Paris.

Weintraub S, Mesulam M. 2009. With or without FUS, it is the anatomy that dictates the dementia phenotype. Brain 132: $2906-2908$.

Weintraub S, Morhardt DJ. 2005. Treatment, education and resources for non Alzheimer dementia: One size does not fit all. Alzheimer's Care Q July/September: 201-214.

Welsh K, Butters N, Hughes J, Mohs R, Heyman A. 1991. Detection of abnormal memory decline in mild cases of Alzheimer's disease using CERAD neuropsychological measures. Arch Neurol 48: 278-281.

Welsh KA, Butters N, Hughes JP, Mohs RC, Heyman A. 1992. Detection and staging of dementia in Alzheimer's disease. Use of the neuropsychological measures developed for the Consortium to Establish a Registry for Alzheimer's Disease. Arch Neurol 49: 448-452.

Wetzel ME, Kramer JH. 2008. The neuropsychology of vascular dementia. In Handbook of clinical neurology (ed. Goldenberg G, Miller B), pp. 567-583. Elsevier, New York.

Whitwell JL, Anderson VM, Scahill RI, Rossor MN, Fox NC. 2004. Longitudinal patterns of regional change on volumetric MRI in frontotemporal lobar degeneration. Dement Geriatr Cogn Disord 17: 307-310.

Whitwell JL, Przybelski SA, Weigand SD, Ivnik RJ, Vemuri P, Gunter JL, Senjem ML, Shiung MM, Boeve BF, Knopman DS, et al. 2009. Distinct anatomical subtypes of the behavioural variant of frontotemporal dementia: A cluster analysis study. Brain 132: 2932-2946.

Wicklund AH, Johnson N, Weintraub S. 2004. Preservation of reasoning in primary progressive aphasia: Further differentiation from Alzheimer's disease and the behavioral presentation of frontotemporal dementia. J Clin Exp Neuropsychol 26: 347-355.

Wicklund AH, Johnson N, Rademaker A, Weitner BB, Weintraub S. 2006. Word list versus story memory in Alzheimer disease and frontotemporal dementia. Alzheimer Dis Assoc Disord 20: 86-92.

Wicklund AH, Johnson N, Rademaker A, Weitner BB, Weintraub S. 2007. Profiles of decline in activities of daily living in non-Alzheimer dementia. Alzheimer Dis Assoc Disord 21: 8-13. 


\title{
$\&_{\mathrm{CSH}}^{\infty} \&$ Cold Spring Harbor

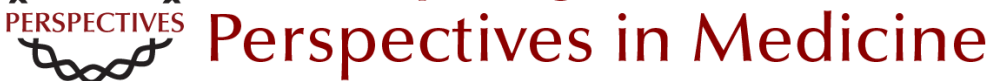

\section{The Neuropsychological Profile of Alzheimer Disease}

\author{
Sandra Weintraub, Alissa H. Wicklund and David P. Salmon
}

Cold Spring Harb Perspect Med 2012; doi: 10.1101/cshperspect.a006171 originally published online January 25, 2012

\section{Subject Collection The Biology of Alzheimer Disease}

Animal Models of Alzheimer Disease

Frank M. LaFerla and Kim N. Green

Neurovascular Dysfunction and Faulty Amyloid $\beta$

-Peptide Clearance in Alzheimer Disease Abhay P. Sagare, Robert D. Bell and Berislav V. Zlokovic

Treatment Strategies Targeting Amyloid $\beta$-Protein Dale Schenk, Guriqbal S. Basi and Menelas N. Pangalos

The Ubiquitin-Proteasome System and the Autophagic-Lysosomal System in Alzheimer Disease Yasuo Ihara, Maho Morishima-Kawashima and Ralph Nixon

Neurotoxicity of Amyloid $\beta$-Protein: Synaptic and Network Dysfunction Lennart Mucke and Dennis J. Selkoe

Proteolytic Degradation of Amyloid $\beta$-Protein Takaomi Saido and Malcolm A. Leissring

Brain Imaging in Alzheimer Disease Keith A. Johnson, Nick C. Fox, Reisa A. Sperling, et al.

Symptomatic and Nonamyloid/Tau Based Pharmacologic Treatment for Alzheimer Disease Paul S. Aisen, Jeffrey Cummings and Lon S. Schneider
Alzheimer Disease in 2020

David M. Holtzman, Eckhard Mandelkow and Dennis J. Selkoe

The Genetics of Alzheimer Disease Rudolph E. Tanzi

Fluid Biomarkers in Alzheimer Disease Kaj Blennow, Henrik Zetterberg and Anne M. Fagan

Epidemiology of Alzheimer Disease Richard Mayeux and Yaakov Stern

Biochemistry and Cell Biology of Tau Protein in Neurofibrillary Degeneration Eva-Maria Mandelkow and Eckhard Mandelkow

Biochemistry of Amyloid $\beta$-Protein and Amyloid Deposits in Alzheimer Disease Colin L. Masters and Dennis J. Selkoe

The Neuropsychological Profile of Alzheimer Disease

Sandra Weintraub, Alissa H. Wicklund and David P. Salmon

Apolipoprotein E and Apolipoprotein E Receptors: Normal Biology and Roles in Alzheimer Disease David M. Holtzman, Joachim Herz and Guojun Bu

For additional articles in this collection, see http://perspectivesinmedicine.cshlp.org/cgi/collection/ 